
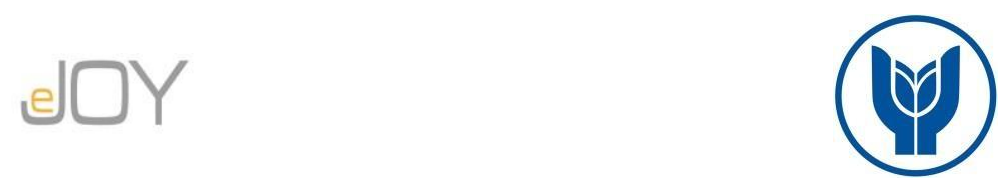

Bahar, M., Topsakal, Y., Yüzbaşığlu, N., Kasalak, M. A. / Journal of Yasar University, 2021, 16/62, 801-816

\title{
The Effect of Casino Tourism and Reentry to the Casino Gaming Industry - The Case of Turkey
}

\section{Casino Turizminin Etkileri ve Casino Oyun Endüstrisine Yeniden Giriş - Türkiye Örneği}

\author{
Mehmet BAHAR, Cappadocia University, Turkey, mehmet.bahar@kapadokya.edu.tr \\ Orcid No:0000-0001-5377-7292 \\ Yunus TOPSAKAL, Adana Alparslan Türkeş Science and Technology University, Turkey, \\ topsakal.yunus@gmail.com \\ Orcid No:0000-0003-3202-5539 \\ Nedim YÜZBAŞIOĞLU, Akdeniz University, Turkey, nedimy@akdeniz.edu.tr \\ Orcid No: 0000-0002-6079-9980. \\ Murad Alpaslan KASALAK, Akdeniz University, Turkey, muradkasalak@akdeniz.edu.tr \\ Orcid No: 0000-0002-4421-1921
}

\begin{abstract}
The economic return of the tourism industry is increasing day by day. Destinations that want to increase their share of this increasing economic return want to attract potential tourists by diversifying the tourism services that they offer. In this context, destinations develop and implement special-interest tourism policies such as dark tourism, gastronomy tourism, ecological tourism, balloon tourism, or casino tourism. Considering the economic benefits of casino tourism, interest in the subject has increased. The main objective of the study is to examine positive and negative effects of the closure of casinos on tourism in Turkey, reveal Turkey's potential within the current casino tourism in the world, identify problems that may arise with casino tourism being allowed, and propose solutions. For this purpose, data were obtained through interviews with 10 hotel managers, who experienced about hotel casinos. The results showed that the closure of casinos in Turkey had negative effects on tourism industry and Turkey has significant casino tourism potential. As a result of interview, it can be suggested that artificially developed a touristic casino city in which entry and exits are made by foreign passport and can be followed with the latest systems can be created. There is paucity research on the reentry of casino tourism in Turkey. The results of study aim to provide insight to strategy and policy makers and relevant institutions.
\end{abstract}

Keywords: Gaming Industry, Casino, Gambling Tourism, Turkey

JEL Classification: L83, Z32, Z38

Öz: Turizm endüstrisinin ekonomik getirisi her geçen gün artmaktadır. Artan bu ekonomik getiriden pay almak veya mevcut payını arttırmak isteyen destinasyonlar ziyaretçilere sundukları turizm hizmetlerini çeşitlendirerek potansiyel ziyaretçileri destinasyona çekmek istemektedir. Bu kapsamda destinasyonlar hüzün turizmi, gastronomi turizmi, ekolojik turizm, balon turizmi, casino (kumar) turizmi gibi özel ilgi turizm strateji ve politikalarl geliştirip uygulamaktadır. Casino turizminin dünyadaki ekonomik getirisi düşünülünce konuya olan ilgi de artmıştır. Bu çalışmanın temel amacı, Türkiye'de casinoların kapatılmasının turizm üzerindeki olumlu ve olumsuz etkilerini incelemek, Türkiye'nin dünyadaki mevcut casino turizmi içindeki potansiyelini ortaya çıkarmak, casino turizmine izin verilmesi ile ortaya çıkabilecek sorunları tespit etmek ve çözümler önermektir. Bu amaçla 10 otelin işletmecisi ile yapılan görüşmeler ile veriler elde edilmiştir. Çalışmanın senaryosuna göre Türkçe görüşmeler yapılmıştır. Türkiye'de faaliyet gösteren 5 yıldızlı büyük ölçekli otel tesislerinden toplam daha önceden casino ile ilgili tecrübesi olan 10 otel yöneticisi ile görüşmeler yapılmıştır. Sonuçlara göre Türkiye'de casinoların kapatılması turizm sektörüne olumsuz etkiye sahipken, ülkemizin şuan büyük bir casino turizmi potansiyeli bulunmaktadır. Görüşme yapılan katılımcıların, Türkiye'de casino turizmi açısından turistik casinoların yeniden açılması konusunda fikir birliğine sahip olduğu belirlenmiştir. Görüşmeler dikkate alınarak, giriş ve çıkışların yabancı pasaportla yapıldığı ve en yeni sistemlerle takip edilebileceği yapay olarak geliştirilmiş bir turistik casino kenti oluşturulması önerilmektedir. Türkiye'de casino turizmine yeniden giriş konusunda çok az araştırma mevcuttur. Çalışmanın sonuçlarının strateji ve politika yapıcılara ve ilgili kurumlara yol gösterici olması hedeflenmiştir.

Makale Gecmisi / Article History

Başvuru Tarihi / Date of Application Kabul Tarihi / Acceptance Date
: 19 Ekim / October 2020

: 1 Mart / March 2021 
Anahtar Kelimeler: Casino Oyunu Endüstrisi, Casino, Şans Oyunu Turizm, Türkiye

JEL Siniflandirması: L83, Z32, Z38

\section{Introduction}

Casino tourism is one type of special-interest tourism and casino tourism visitors are increasing steadily. Casino tourism can be defined as the casino tours of tourists inspired by the desire for entertainment and the experiences offered to casino visitors (Bulatovic et al., 2017). Leiper (1989) was one of the first researchers to describe the relationship between tourism and casinos and suggested the typology of casino visitors, highlighting the distinct difference between 'seekers of passion for travel' (tourists who want to explore the destination and enjoy wildlife and nature) and 'seekers of the sun' (tourists seeking the sun, sea, and sand). Leiper's (1989) study revealed that tourists with a passion for travel tend to participate less in casino tourism compared to tourists looking for sun. Casinos can form a part of tourism products. They can be offered to tourists as a package or with other tourism products to provide an enhanced entertainment experience for tourists. However, casino tourists may show a different socio-demographic profile in terms of age, income, educational level, marital status, and educational level (Morrison et al., 1996).

One of the most important features of casino tourism is that it can bring a large number of people together from various countries and gather them in one place. Other industries can also take advantage of this, as there are many people around casinos. The hotel industry is a sector that will benefit from casino tourism firstly and significantly (Tore, 2019). There are many studies on the negative and positive effects of casino tourism development, but casino tourism studies are almost always done with negative assumptions. The main negative effects on social and economic environments are increased crime, addictive playing of casino games, and money loss (Persson, 2008).

Casino tourism has many economic benefits, such as tax revenues and job creation, increased income for local residents, and protection of local traditions. Economic benefits are the main reason for destinations to develop casino tourism ( $\mathrm{Wu}$ and Chen, 2015). Apart from tax revenues, tourism investments increase with casino tourism and the economic situation of non-privileged groups can be improved (Persson, 2008). Turkey has been deprived billions of dollars in revenue because of both foreign and domestic tourists turns to other countries for over 20 years because of the closed casinos (Ates and Sunar, 2019). In this respect, casino tourism plays an important role in the elimination of the unjust income distribution that has occurred in society. Casino tourism allows people with relatively low-income levels to earn 
an income from these expenditures ( $\mathrm{Wu}$ and Chen, 2015). In addition, the input provided by tourism in general and specifically casino tourism to fifty-four sectors is another example of the impact of the socio-economic benefits (AKTOB, 2014). On the contrary, Fink et al. (2004) and Borg et al. (1993) argued that as casino revenues increased, general government revenues decreased. Siegel and Anderson (1999) found in their study that a $10 \%$ increase in the income from casino taxes, decreased other recreation and entertainment tax revenues by $4 \%$.

Turkey have been prepared regulations, laws and regulations about casinos. Within the scope of "Games of Chance" as issued in accordance with the 19th article of the Tourism Encouragement Law, numbered 2634 and published in Official Gazette Number 17992 on 18.1.1983, it was allowed to open venues for games of chance in Turkey. These casinos had 848 game tables and 8,979 game machines. Casinos paid nearly \$2.3 million in value-added tax to the government in the year before they were closed (Turizm Aktuel, 2018). Casinos has been made legal in Turkey in 1983 to attract overseas tourists and encourage investments to tourism industry. At first, Turkish citizens were prohibited from entering casinos. However, in 1995, Turkish citizens could enter casinos in Northern Cyprus. Increased gambling problems such as increase in organized crime and corruption in Turkey has become negative view against the casino. Therefore, the 78 casinos were closed in 1997 in Turkey (Duvarc1 et al., 1998).

Casinos and gambling are a social and historical phenomenon that is viewed as an unwanted and perilous activity. Because of this, casinos are considered to be banned and are prohibited in most countries. However, with the increase of illegal casinos, social problems have started to increase more (Catarino et al., 2020). In the case of any crisis experienced in Turkey, the tourism sector is expected to undergo a major loss. It is necessary to focus on more tourism types and to diversify tourism products in order for the tourism industry to be less affected in times of crisis. According to the development trends of previous years, the economic size of casino tourism is estimated to reach \$525 billion in 2023 (Gambling Market Report, 2018).

The prohibition of casinos in 1998 in Turkey deprived the tourism sector of tremendous income (Ates and Sunar, 2019). There is paucity research on the reentry of casino tourism in Turkey and take a share from casino market. In this context, main objective of this study is to examine positive and negative effects of the closure of casinos on tourism in Turkey, reveal Turkey's potential within the existing casino tourism, identify problems that may arise with casino tourism being allowed, and propose solutions. 


\section{Casino Tourism and Its Effects}

Casinos are organizations in which people can participate in various types of games and the casino industry earns high income from these activities. Casinos worldwide had an estimated gross income of $\$ 115$ billion in 2016, and this figure was estimated to have reached an average of $\$ 130$ billion for 2019 (Lock, 2018). Social casino players are also increasing every year. Macau, a special administrative district of China, became the world's largest casino market, leaving behind Las Vegas, the former leader, in 2006. Casinos contribute increasingly to Macau's economy every year, and gross casino revenue increased from $\$ 10.5$ billion in 2007 to $\$ 32$ billion in 2017 (Statista, 2020). Las Vegas, located in Nevada in the USA, is now the second largest and perhaps the most famous casino market. Like Macau and other game markets, most casinos in Las Vegas are in a touristic area that includes casinos as well as large resorts and entertainment facilities. This tourism center attracted approximately 39 million visitors in 2017, a number that grows annually (Lock, 2018). Most of the economic benefits from casinos can be attributed to tourism in one way or another (Eadington, 1999).

While the presence of casinos provides significant economic benefits, it should be noted that such developments also have social and environmental impacts that will ultimately affect the local community. The main positive effects of casinos include significant economic benefits, such as an increase in the number of new jobs for residents. Positive socio-cultural influences include the enrichment of cultural content, the preservation of cultural and historical complexes and buildings with recreation and leisure activities (Bulatovic et al., 2017). Long (1996), examining the effects of the casino industry, found that legal reports generally included unexpected problems, new pressures, the need for constant monitoring, and similar concerns. Extensive research (Anders, 1996; Byron and Quiggin 1996; Cotti, 2008; Farrigan, 2005; Fenich and Hashimoto, 2004; Hashimoto and Fenich, 2003; Marshall, 1998) has been conducted in the past focusing on the possible effects of casino games. Most of these studies are based on 1970s tourism impact studies (Hsu, 2000). Possible effects of casinos are generally classified as social, economic, and environmental effects and these effects are both positive and negative (Lee and Back, 2003).

Opening casinos can increase opportunities for the local community, such as recreation and entertainment. Crown Casino in Melbourne, Australia, is not only a gaming facility but also offers other entertainment, restaurants, bars, and retail outlets (Buultjens, 2006). Although Long (1996) perceived that local communities of South Dakota and Colorado generally had positive impacts from casinos in terms of employment, they also identified negative effects such as traffic congestion and overcrowding. Lee and Back (2006) stated that 
the casino industry produces positive local environmental results, including the protection of the natural environment and ecological resources, protection of historical buildings and cultural heritage, improvement of public transportation, improvements in infrastructure, higher medical standards, increased recreational areas, and the revitalization of the city.

Giacopassi et al. (1999) interviewed 128 heads of non-governmental organizations in seven new casino areas in the USA. The authors concluded that $59 \%$ of the participants preferred having the casinos and $65 \%$ believed that the casinos improved the quality of life. It has been reported that casino games in Atlantic City in New Jersey have led to the redevelopment of tourism and congress facilities and the improvement of infrastructure and tourism capacity (Nicholas, 1998). Establishing casinos can increase the recreation, entertainment, and recreation opportunities of the local community (Wan et al., 2011).

Janes and Collison (2004) reported that there was no direct link between casino development and criminal activity. Giacopassi et al. (1999) stated that casinos have little effect on crime rates. In the research of Grinols and Mustard (2006) that dealt with the relationship between the number of casinos in a region and crime rates, both positively and negatively, they suggested two potential situations in which casinos can reduce crime. First, if casinos offer better job opportunities for low-skilled employees, crime may fall. Second, economic developments from casinos can have effects to reduce crime. Lan et al. (2020) conducted research to determine the micro and macro effects of a casino on crime types over time. According to the findings, the impact of the casino on violence and property crimes changes over time. When the casino first opened, the crime rate tended to increase around casino. However, as the city, where the casino is located, has experience in casino, the crime rate in the city decreases over time (Lan et al., 2020).

Casino games can trigger local economic development and create more business opportunities (Kang et al., 2008). Economic benefits have been one of the most widely debated issues regarding the positive aspects of casino development. When the research on the subject is examined, it is believed that the reason for almost all locales to start developing casino facilities is the economic benefit (Vong and MacCartney, 2005). The development of new business opportunities is one of the possible positive effects when casinos are opened. New workforces are needed with casinos (Carmichael, 2001). For example, 34,364 jobs were generated in the Iowa, USA due to casinos and tourism in general (Chhabra, 2007).

Gonzales et al. (2007) determined that casinos in Arizona and New Mexico enabled improvements in quality of life in terms of the social and economic well-being of the local people. Wan et al. (2011) investigated the social consequences of casino games in Macao. 
These consequences are that increasing casinos allows for increased personal income and the financial strength of the city. In addition, it has been revealed that an increase in casinos brings certain social benefits to society, such as the improvement of landscaping, infrastructure, and facilities and the increase of recreational facilities. Similarly, the increase in income from gaming tax has increased the benefits of Macau's citizens via countless financial resources (Benton, 2015).

Balazic (2016) examined socio-economic indicators to determine the contribution of casino tourism to the regional development of Istria, Slovenia. The results showed that casino tourism is an important factor of regional development. Bulatovic et al. (2017) interviewed 14 casino players to demonstrate and evaluate the current status and potential of casino tourism in Montenegro. The results showed that casino tourism in Montenegro is not developing enough.

Casinos also have a significant number of negative effects, such as increased living expenses, traffic congestion, increased driving hazards and increased crime rates in the local community (Bulatovic et al., 2017). Casino tourism has an important role on other sectors according to the location of the casino and the type of casino. Sectors negatively affected by casino tourism are manufacturing, agriculture, mining and retailing. Sectors positively affected by casino tourism are the alcohol sector, real estate, insurance, finance, and construction sectors (Marionneau and Nikkinen, 2020). Philander and Bernhard (2012) in their research determined that casino tourism does not have any negative impact on other sectors in the region. On the contrary, they stated that sectors such as accommodation, restaurant, and entertainment benefit from casino tourism. Vong (2008), on the other hand, determined that most of the local people of Macau believe that the casino games and the growing economy led to a high lifestyle and therefore lead to an increase in property prices.

But and Ap (2017) examined the impact of casino tourism on the lives of local populations and the consequences of poverty and all inequalities. Stokowski (1996) analyzed Colorado's two casino towns, Black Hawk and Central City, and concluded that crime increased with increasing casinos. Similarly, Long (1996) determined that residents of South Dakota and Colorado often perceived casinos as causing increased crime.

The social effects associated with casinos are inherently difficult to measure. Conceptually, it is stated that the negative social impact is caused by excessive gambling. The negative effects of gambling are in many ways parallel to those caused by alcohol consumption (Eadington, 1999). Pathological gamblers are therefore paralleling with heavy drinkers / alcoholics and create difficulties not only for themselves but also for other members 
of the community and society in general. It is more difficult to obtain empirical dimensions of problem gambling with any degree of credibility. The prevalence of problem gambling is more difficult to measure than problem drinking prevalence because there are fewer physical connections (Howard et al., 1997).

\section{Methodology}

The main purpose of this study is to examine positive and negative effects of the closure of casinos on tourism in Turkey, reveal Turkey's potential within the existing casino tourism, identify problems that may arise with casino tourism being allowed, and propose solutions. Data were collected through interviews, a data aggregation technique of qualitative research (Minichiello et al., 2004). Via interviewing, which is a data collection technique frequently used in qualitative research, the interviewees can express themselves first-hand, and the researcher also can deeply understand the emotional worlds, perspectives, emotions, and experiences of the special situations in which they are interviewed (McCracken, 1988). The interview was chosen because it is a highly effective method for obtaining information about the individual's experiences, attitudes, opinions, complaints, feelings, and beliefs (Y1ldırım and Şimşek, 2006).

In an interview, the interviewee is asked to answer pre-determined, standard questions (Punch, 2005). In this context, it was deemed appropriate to collect data within the scope of the following questions with individual interviews:

- Question 1: How has tourism been affected both positively and negatively with the closure of casinos in Turkey?

- Question 2: What is the current potential of Turkey in terms of casino tourism? What do you think about Turkey's infrastructure and superstructure for casino tourism (airlines, transportation, labor, hotel capacity, etc.)? Can you evaluate this?

- Question 3: Do you think Turkey should re-open casino tourism? If so, what are your suggestions for legal regulations on casino tourism?

- Question 4: What are your suggestions for potential problems that may arise regarding the re-opening of casino tourism in Turkey? How can casino tourism be made successful in Turkey?

Interviews were conducted in Turkish. Participants were selected from those with previous hotel casino management experience. Volunteering was taken as a basis in determining the participants. Interviews were held with a total of 10 hotel managers of 5-star large-scale hotel facilities (coded as A1-A10), 6 in Antalya, 2 in Muğla, 1 in Bursa, 1 in 
Kayseri, Turkey. The selected hotel managers are already experienced and knowledgeable about casino tourism. The interviews were held between 08.12.2019 and 27.12.2019. Demographic characteristics of the participants are given in Table 1.

Table 1. Demographic Characteristics of Participants

\begin{tabular}{crcc}
\hline Participant & Age & Years Working in Tourism & Years of Casino Experience in Turkey \\
\hline A1 & 48 & 26 & 5 \\
A2 & 40 & 22 & 1 \\
A3 & 49 & 32 & 11 \\
A4 & 50 & 30 & 9 \\
A5 & 48 & 25 & 4 \\
A6 & 51 & 34 & 13 \\
A7 & 47 & 28 & 7 \\
A8 & 50 & 33 & 12 \\
A9 & 54 & 34 & 14 \\
A10 & 47 & 25 & 6 \\
\hline
\end{tabular}

Feedbacks given to open-ended questions provided by each participant were grouped by Miles and Huberman (1994) classification method according to the stages of data collection, data reduction, data presentation and conclusion, and frequency and percentage calculations were made. While interpreting the findings, both the frequencies and percentages, and the participants' own expressions were used by making direct quotations. This grouping was tested for reliability by an expert instructor.

There are several validity and reliability measures that ensure the accuracy and repeatability of the results obtained from qualitative research (Yıldırım and Şimşek, 2006). To ensure the internal validity of this study, the participants who had a conversation with them before the interview; they have been informed about the purpose of the study and have gained confidence that their personal information will never be used. Later, among the data obtained from the participants during the interview, those considered to be important were noted at the time of the interview. To ensure the clarity of the noted data, participant confirmation was obtained in this way by obtaining the consent of the participants whether the words in these important points were understood correctly by the researcher during or after the interview. For the external reliability of the study, it was tried to express clearly how the interview was conducted and how obtained data were analyzed. In addition, the raw data of the study are also recorded and kept by the researchers. For internal reliability, only the statements of the participants were included in the form of direct quotations in the whole of the findings section, without the comments of the researchers. In addition to the fact that the study was carried out by four researchers regarding the reliability of the data, approvals of two different 
faculty members were also obtained on issues such as the consistency of the research questions and the reflection of the data.

\section{Findings and Discussion}

According to the answers to the first question directed to the participants, how tourism has been affected both positively and negatively by the closure of the casinos in Turkey, it has been determined that the closure of the casinos negatively affected tourism in Turkey. Two important responses are as follows:

There are serious casino customers in the world. After casinos closed in Turkey, casinos tourists were no longer coming to Turkey (A5).

The closure of casinos had a serious impact on the reduction of tourism revenues. The revenues Turkey lost as a country has gone to many other countries, especially Bulgaria, because now that country began to serve the casino tourists that were coming to Turkey. Instead of approaching the problems by closing the casinos, casino tourism could continue with legal solutions (A8).

As a result of the interview question about Turkey's current casino tourism potential, infrastructure, and superstructure, it was seen that 6 of the participants were of the opinion that Turkey already has casino tourism infrastructure and superstructure. The other two participants said that Turkey has casino tourism potential, but the infrastructure and superstructure are not ready. However, these two participants also stated that due to Turkey's past experience in casino tourism, the required infrastructure and superstructure can be created quickly. Some noteworthy views are as follows:

Turkey has a high potential in terms of casino tourism. Turkey is better than many countries in terms of infrastructure. There are flights to most countries from international airports, especially in tourism destinations such as Antalya or Izmir (Al).

Due to Turkey's geographic location, there are flights between countries with 4-5 hour flight distances and these countries have many casino customers. Strategically, Turkey's location provides the potential to serve many casino customers from neighboring countries. Considering that the old hotels in our country were generally built as casino hotels, Turkey already has infrastructure and superstructure for casino tourism (A5).

Antalya is one of the best locations for casino tourism, especially since the Titreyen Lake is a narrow area. Due to the fact that it is in a narrow area in terms of both sea 
and hotels, there may be entrance and exit control, like abroad. There are places with potential for control like this in Turkey. Infrastructure and superstructure are suitable, hotels have lounges for casino tourism, and there are flights to almost everywhere from Turkey (A6).

First of all, Turkey has past experience in terms of casino tourism. Casinos were benefiting more in the winter season. There is not much left in terms of infrastructure right now, but it doesn't take a long time to rebuild them. Investors who have made previously required infrastructure and superstructure investments in Turkey may soon do it again (A8).

In line with the answers of the participants about Turkey's casino tourism, it can be said that Turkey has great potential. Themes on existing infrastructure within Turkey's casino tourism sector and their frequencies are given in Table 2.

Table 2. Existing Infrastructure of Casino Tourism in Turkey

\begin{tabular}{ll}
\hline Themes & Frequency \\
\hline Existing airports are sufficient & 5 \\
Existing hotels are appropriate & 4 \\
Existing flight routes are sufficient & 3 \\
Existing staff is adequate & 3 \\
\hline
\end{tabular}

As can be seen in Table 2, the participants stated that four basic types of infrastructure are suitable and sufficient for casino tourism in Turkey. These are the available airports, available hotels, available flight routes, and available staff. Turkey has a large advantage because there are many international flights routes to Turkey. Furthermore, due to the fact that casino tourism was already established once before in Turkey, it can be said that Turkey already has most of the infrastructure and superstructure required for casino tourism.

Regarding the possible problems of casino tourism, it was determined that problems are caused by local people having access to touristic casinos. Therefore, the participants proposed that Turkey should determine areas such as islands, closed areas, or free trade zones for casino tourism and re-open casinos in these specific areas. It was also stated that foreign passports should be required when entering and exiting touristic casinos, as is done in some other countries, and punishments must be deterrent. Some statements considered important in this context are as follows:

Casino tourism should be allowed where single entry is single exit and not open to all. For example, casino tourism should be done in private regions such as in Datça, Cappadocia, or Antalya (A2). 
Only certain places should be allocated for casino tourism, for example, an island with easy entry-exit control (A3).

There are casino regions in some countries in Europe and casino tourism can be carried out in a controlled way. Turkey's Antalya Expo area in the context of the newly built casino is very suitable for tourism. By establishing a passport entry-exit system into the expo area, a casino tourism area can be created here (A5).

The restricted areas can be reconstructed for casino tourism in Turkey. First, a pilot zone can be established (A9).

Participants agreed about the re-opening of touristic casinos in terms of casino tourism in Turkey. In this context, they suggested that casinos cannot be opened outside of casino tourism areas as a legal regulation and that entry and exit to these areas should be done with foreign passports, providing the latest technological systems and controls and deterring punishments. The participants emphasized the importance of preparing all legal arrangements within the scope of common views among the tourism industry, state bodies, and NGOs. In this regard, some important statements are as follows:

Casino tourism should be done in a closed area like Las Vegas and it should definitely be closed to the local people (A1).

Clear decisions must be made about who will serve whom and the market. Casino tourism should be carried out in places where entrance and exit can be easily controlled, such as private free zones (A2).

Turkish citizens should be banned from entering. There is no need to open casinos in closed areas, because the technology has advanced and the state can control everything easily with the latest systems (A4).

Casino tourism should be done in special areas such as the Antalya Expo area with a single entrance and exit, where passport control can be done (A5).

For example, in casinos, some nightly loss limits can be determined for people. These limits can be determined according to the stars and location of the hotel where the casino operates. The casino limit should be determined by legal regulations, like a credit card limit for people. Game limits such as withdrawal limits should be given, like at ATMs. Thus, controls can be provided. These should be made by law (A10).

When the results are evaluated in general, the participants are in agreement about reopening casino tourism in Turkey. It was determined that Turkey has the capacity for re-entry into the casino gaming industry in the context of infrastructure and superstructure. 


\section{Conclusion and Implementation}

It is necessary to consider casino tourism in terms of two aspects. First, the potential casino tourists expected to come to Turkey for casino tourism must be considered. From this point of view, it is possible to reach more than 1.5 billion people due to Turkey's geographical location and 4-hour flights from more than 60 countries (Turkey Discover Potential, 2019). In addition, the number of countries from which Turkey does not require a visa or gives e-visas is 117, and this number represents a good opportunity for tourism (eVisa, 2020). Turkish Airlines, a national brand that flies to most of the world, also strengthens the casino tourism potential of Turkey (Sagliktaturizm, 2019). Turkey is deprived of casino tourism income, which had reached $\$ 115$ billion as of 2016 in world (Statista, 2021), due to the closure of its casinos. However, even without casino tourism in Turkey, this income is still being generated around the world by casino tourism. The infrastructure of hotels in Turkey and infrastructure of potential regions that can be planned for casino tourism are suitable. Therefore, casinos in Turkey can be easily re-opened after legal arrangements are made to prevent possible negative effects and to get a share from this existing market. Thus, per capita tourist expenditures can be increased, and due to the foreign exchange revenues, it will also generate positive contributions to the deficit in the 'balance of payments' that Turkey's economy recently faces.

A significant population in Turkey has a habit of gambling. A significant number of these people go abroad to satisfy the habit or they go to illegal casinos. Therefore, Turkey suffers significant foreign currency losses, and illegal casinos generate unregistered and untaxed earnings. In addition, because this existing demand is not met, individuals are encouraged to commit crimes due to illegal possibilities. The main task of the state is to prepare appropriate situations and environments that will prevent its citizens from committing such crimes rather than encouraging its citizens towards crime.

When all these issues are taken into consideration, our suggestion is that casinos should be allowed to re-open immediately by removing barriers to casino tourism. Therefore, the areas in which casino tourism will exist can be controlled, with entrance and exit to be determined near major tourist attractions and in areas that are not generally accessible to the city and the local people, but that can be easily reached by the tourists. Enterprises to be opened here should be supported.

In addition to the opportunity for foreign tourists to fulfill these needs, the use of these places should be ensured with legal arrangements to be made for those who have this passion in the domestic market and who can afford it economically. Namely, due to the development of today's technological infrastructure, the credibility of both individuals and institutions can 
be reviewed in seconds and positive or negative answers can be obtained. Therefore, with a database to be created for this issue, it should be possible to identify people with sufficient economic levels in this regard and to allow them access to these places if appropriate. Possible negative changes in the credibility of the person as a result of losses due to casinos or other economic activities should be monitored through such big data and updated instantly, and people who fall below a certain economic level should be restricted. In this way, social problems that may occur can be prevented. Applications such as iris scanning, fingerprinting, or subcutaneous chips can be provided for people with legal permission to ensure that the gambling permission to be obtained legally is not used by unauthorized persons.

Casino tourism venues to be created will increase the per capita guest income as well as allowing 12 months of activity, extending the season, increasing employment opportunities, and reviving the subsidiary sectors that provide services to casinos. Especially the entertainment sector, which is a subsidiary sector of casino tourism, will develop further and will trigger the establishment of entertainment centers that will benefit those who do not gamble.

In addition, the special legal permits to be given to those who want them and can gamble, the real tendency to gambling that already exists in society can be recorded. In this way, by monitoring people with this passion and their ratio to the general population, if this trend increases more than expected, research can be conducted to prevent this situation by investigating its sociological causes. In this way, a positive contribution can be made to public health. 


\section{REFERENCES}

AKTOB (2014). Turizm sektörünün yapısı, büyüklüğ̈̈ ve ekonomiye katkısı. Antalya: Retma Matbaa.

Anders, G. (1996). Native American casino gambling in Arizona: A case study of the Fort McDowell reservation. Journal of Gambling Studies, 12(3), 253-267.

Ates, A. \& Sunar, H. (2019). An application proposal for reintegration of casinos to Turkish tourism. Proceedings of the Innovation and Global Issues Congress V, Ankara, Turkey, pp. 237-244.

Balazic, G. (2016). The socioeconomic impacts of casino tourism in Slovenia's Obalno-Kraska Region. Studies in Business and Economics, 11(3), 150-163.

Benton, C. (2015). The economic and social effects of casino development in Macau. Unpublished Master Thesis, University of Nevada, Las Vegas.

Borg, M. O., Mason, P. M. \& Shapiro, S. L. (1993). The cross effects of lottery taxes on alternative state tax revenue. Public Finance Quarterly, 21, 123-140.

Bulatovic, I., Stranjancevic, A., Lacmanovic, D. \& Raspor, A. (2017). Casino business in the context of tourism development (case: Montenegro). Social Sciences, 6(4), 2-16.

But, J. W. P. \& Ap, (2017). The impacts of casino tourism development on Macao residents' livelihood. Worldwide Hospitality and Tourism Themes, 9, 260-273.

Buultjens, J. (2006). Wage determination in NSW and Queensland clubs. Journal of Hospitality and Tourism Administration, 7(2/3), 135-153.

Byron, P. \& Quiggin, J. (1996). Economic impact of the Brisbane casino. Australia: James Cook University.

Carmichael, B. (2001). Casinos, communities and sustainable economic development. In S. F. McCool \& R. N. Moisey (Eds.), Tourism, recreation and sustainability (pp. 217-231). Wallingford: CABI Publishing.

Catarino, J. R. \& Cordeiro, J. D. (2020). Impacts of the online gambling prohibition policy - a comparative survey of Brazil versus the European Union. Sequência (Florianópolis), 85, 51-85.

Chhabra, D. (2007). Estimating benefits and costs of casino gambling in Iowa, United States, Journal of Travel Research, 26(2), 173-182.

Cotti, C. (2008). The effect of casinos on local labor markets: A county level analysis. Journal of Gambling Business and Economics, 2(2), 17-41.

Duvarc1, I., Varan, A., Coşkunol, H. \& Ersoy, M. (1997). DSM-IV and the South Oaks Gambling Screen: Diagnosing and assessing pathological gambling in Turkey. Journal of Gambling Studies, 13(3), 193205.

Eadington, W. R. (1999). The spread of casino and their role in tourism development. Abington: Routledge.

eVisa (2020). https://www.evisa.gov.tr/tr/ 25 January 2021.

Farrigan, T. (2005). The Tunica miracle, sin and savior in America's Ethiopia: A poverty and social impact analysis of casino gaming in Tunica. Unpublished Dissertation, Mississippi, Pennsylvania State University.

Fenich, G. \& Hashimoto, K. (2004). Perceptions of cannibalization: What is the real effect of casinos on restaurants?. Gaming Law Review, 8(4), 247-259.

Fink, S. C., Marco, A. C. \& Rork, J. C. (2004). Lotto nothing? The budgetary impact of state lotteries. Applied Economics, 36, 2357-2367.

Gambling Market Report (2018). Gambling market - global outlook and forecast 2018-2023. Dublin: ARIZTON.

Giacopassi, D., Nichols, M. \& Stitt, B. G. (1999). attitudes of community leaders in new casino jurisdictions regarding casino gambling's effects on crime and quality of life. Journal of Gambling Studies, 15(2), 123-147.

Gonzales, A. A., Lyson, T. \& Mauer, K. W. (2007). What does a casino mean to a tribe? Assessing the impact of casino development on Indian reservations in Arizona and New Mexico. Social Sciences Journal, 44(3), 405-419.

Grinols, E. L. \& Mustard, D. B. (2006). Casinos, crime, and community costs. The Review of Economics and Statistics, 88(1), 28-45.

Hall, C. M. \& Weiler, B. (1992). Introduciton. What's special about special interest tourism?. In Weiler, B. \& Hall, C. M. (Eds.), Special interest tourim. England: Belhaven Press.

Hashimoto, K. \& Fenich, G. (2003). Does casino development destroy local food and beverage operations? Development of casinos in Mississippi. Gaming Law Review, 7(2), 101-109.

Howard, J. S., Matthew N. H. \& Joni, V. B. (1997). Estimating the prevalence of disordered gambling behavior in the United States and Canada: A meta-analysis. Boston: Harvard Medical School.

Hsu, C. H. C. (2000). Residents' support for legalized gaming and perceived impacts of riverboat casinos: changes in five years. Journal of Travel Research, 38(4), 390-395.

Janes, P. L. \& Collison, J. (2004). Community leader perceptions of the social and economic impacts of Indian Gaming. UNLV Gaming \& Review Journal, 8(1), 13-30. 
Kang, S. K., Lee, C. K., Yoon, Y. \& Long, P. T. (2008). Resident perception of the impact of limited-stakes community-based casino gaming in mature gaming communities. Tourism Management, 29(4), 681694.

Kent-Lemon, N. (1988). New gambling markets in Turkey. In Eadington, W. R. (Ed.), Gambling Research: Proceedings of the Seventh National Conference on Gambling and Risk Taking (pp. 401-411). Reno: University of Nevada Press.

Lan, M., Liu, L. \& Eck, J. (2020). A spatial analytical approach to assess the impact of a casino on crime: An example of JACK Casino in downtown Cincinnati. Cities, Article No: 103003.

Lee, C. K. \& Back, K. J. (2003). Pre-and post-casino impacts of residents' perception, Annals of Tourism Research, 30(4), 868-885.

Lee, C. K. \& Back, K. J. (2006). Examining structural relationships among perceived impact, benefit and support for casino development based on 4 year longitudinal data. Tourism Management, 27(3), 466-480.

Leiper, N. (1989). Tourism and Gambling. GeoJournal, 19, 269-275.

Lock, S. (2018). Casino industry - statistics \& facts. [Online] Available: https://www.statist a.com/topics/1053/casinos/ Accessed 28 December 2019.

Long, P. T. (1996). Early impacts of limited stakes casino gambling on rural community life. Tourism Management, 17, 341-353.

Marionneau, V. \& Nikkinen, J. (2020). Does gambling harm or benefit other industries? A systematic review. Journal of Gambling Issues, 44, 4-44.

Marshall, D. (1998). Missing the jackpot? The proliferation of gambling in Australia and its effect on local communities. Australian Geographical Studies, 36(3), 237-247.

McCracken, G. (1988). Grant, the long interview. London: Sage Publications.

Miles, B. M. \& Huberman, A. M. (1994). Qualitative data analysis. London: Sage Publications.

Minichiello, V., Madison, J., Hays, T. \& Parmenter, G. (2004). Doing qualitative in-depth interviews. In V. Minichiello, G. Sullivan, K. Greenwood \& R. Axford (Eds.), Research methods for nursing and health science (pp. 411-446). Australia, New South Wales: Pearson Education.

Morrison, A. M., Braunlich, C. G., Liping, A. C. \& O’Leary, J. T. (1996). A profile of the casino resort vacationer. Journal of Travel Research, 35(2), 55-61.

Nicholas, M. W. (1998). The impact of deregulation on casino wins in Atlantic City. Review of Industrial Organization, 13, 713-726.

Persson, A. (2008). Sustainable development in a rapid developing casino destination: The case of Macau. Unpublished Bacheor Thesis, Baltic Business School, University of Kalmar.

Philander, K. \& Bernhard, B. (2012). Informing the public debate: Cannibalization. The effect of new casinos on gaming and non-gaming businesses. Las Vegas: UNLV International Gaming Institute.

Punch, K. F. (2005). Introduction to social research - quantitative \& qualitative approaches. London: Sage.

Sağllktaturizm (2019). Why foreign patients prefer Turkey. [Online] Available: https://sagliktaturizm.com/ Accessed 28 December 2019.

Siegel, D. \& Anderson G. C. (1999). Public policy and the displacement effects of casinos: A case study of riverboat gambling in Missouri. Journal of Gambling Studies, 15, 105-121.

Statista (2020). Gambling industry in Macao. [Online] Available: https://www.statista.com/study/68768/gamingand-gambling-industry-in-macao/ Accessed 21 January 2021.

Statista (2021). Global casino market gross gaming yield (GGY) from 2001 to 2019 (in billion U.S. dollars). https://www.statista.com/statistics/271577/global-casino-gaming-market-revenue/ Accessed 26 January 2021.

Stokowski, P. A. (1996). Crime patterns and gaming development in rural Colorado. Journal of Travel Research, 34(3), 63-69.

Tore, O. (2019). Casino tourism: the relationship between casino and tourism. [Online] Availbale: https://ftnnews.com/other-news/36589-casino-tourism-the-relationship-between-casino-and-tourism Accessed 27 December 2019.

Trauer, B. (2006). Conceptualizing special interest tourism - framework for analysis. Tourism Management, 27, 183-200.

Turizm Aktuel (2018). Casinolar geri mi geliyor? [Online] Available: http://www.turizm aktuel.com/haber/casinolar-geri-mi-geliyor Accessed 27 December 2020.

Turkey Discover Potential. (2019). Strategic Location. Turkey Discover Potential: https://www.askturkiye.com/en Accessed 25 Januarry 2021.

Vong, F. C. K. \& McCartney, G. (2005). Mapping resident perceptions of gaming impact. Journal of Travel Research, 44(2), 177-187.

Vong, F. C. K. (2008). Influence of personal factors on Macau residents' gaming impact perceptions. Gaming Research \& Review Journal, 12(1/2), 15-28.

Yıldırım, A. \& Şimşek, H. (2006). Sosyal bilimlerde nitel araştırma yöntemleri. Ankara: Seçkin. 
Bahar, M., Topsakal, Y., Yüzbaşığlu, N., Kasalak, M. A. / Journal of Yasar University, 2021, 16/62, 801-816

Wan, Y. K. P., Li, X. C. \& Kong, W. H. (2011). Social impacts of casino gaming in Macao: A qualitative analysis. Tourism: An International Interdisciplinary Journal, 59(1), 63-82.

Wu, S. T. \& Chen, Y. S. (2015). The social, economic, and environmental impacts of casino gambling on the residents of Macau and Singapore. Tourism Management, 48, 285-298. 